\title{
ISLAMIC THOUGHT, NATIONALISM, AND MULTICULTURALISM
}

\author{
Zuly Qodir \\ Muhammadiyah University of Yogyakarta
}

\begin{abstract}
The inclusive interpretation of religious texts will contribute to the development of plural and multicultural theological perspective rather than develop anexclusive and closed theology. There is a lot of momentum which can serve as a point of departure for developing multicultural theology in Indonesia when humanitarian issues are faced by so many believers, especially the Muslims, such as floods, earthquakes, landslides, and ignorance that continue to haunt the entire country rather than busy interfering with other people's faith. Judging by very diverse field conditions, there is a final note regarding multiculturalism in the context of Islam in Indonesia. There are internal and external problems that affect religious understanding in this country. The internal factors are the existence of a highly diverse understanding, from moderate, progressive to conservative, thus influencing each other's understanding of the Indonesian Muslims. The internal factor cannot be underestimated for it is perceived to be influential in the community, so it has to be an understanding that is able to push the development of multiculturalism and pluralism in Indonesia. Meanwhile the external factors should also get attention in this study.
\end{abstract}

Keywords: Islam, perspective, multiculturalism, and Indonesia.

\section{INTRODUCTION}

Discussion about multiculturalism in Indonesia is relatively new, particularly after earlier discussionsfilled with the term pluralism have been growing since the 1990's. However, the discussion about pluralism since the 1990s until the present day has been filled with controversy. A little different to the term multiculturalism, though later the term was also questioned because of the suffix 'ism' that is considered very close to other terms such as secularism, liberalism, communism and socialism. A growing controversy, of course, will not improve Indonesia's conditions. Equality, well-being, and public order --expected to continue to grow in the country-- are in fact difficult to develop when the controversy over the terms continues without satisfactory explanation. Therefore, it takes an effort that minimizes and enables new insights and opens discourse about multiculturalism in Indonesia.

Indonesia is a country with a lot of ethnic, religious, tribal, and social 
groups. It is even multicultural in terms of just about anything and there is no question about it.However, the terms multiculturalism and pluralismwill immediately be rejected particularly bymost Muslims who are willing to use the words such asplural and pluralistic, multicultural, but are not willing to use the termspluralism or multiculturalism. The discussion about the two terms above needs to be done in order to increasingly open and develop insights and discourse on pluralism and multiculturalism in the country.

In the religious context, inter-religious issues are often present in a society. This happens because the question of inter-religious issues in fact always involves a religious emotion, called religious commitment and religious claim which allows one to be the most loyal follower. In fact, the issues of religious commitment and religious claim cannot be denied, in a more positive perspective, which may lead to viewing other groups as partners in interreligious dialog. Activists should promote intercultural and inter-religious dialogs so that the tradition of dialogwill be encouraged. This is to avoid any social conflict based on theological backgrounds.

Socio-religious conflict can be minimized when groups are willing to acknowledge the presence of others who are different. Appreciatingand at the same time acknowledging the other groups across their own beliefs is where the principle of multiculturalism becomes very important. Socio-religious conflict would thus decrease when religious groups either internally or externally are open and mutually respect and recognize the presence of others. The consequences that will ensue from such an attitude is the existence of a will to make religious texts that can be interpreted by a lot of people whereas such interpretation should be relative.

The study in this paper will focus on the use of the term multiculturalism which is adopted in several occasions together with the term pluralism, though the two are actually very different in meaning. Some use the term pluralism to describe the religious context, while the term multiculturalism is used to describe issues that are closely related to socio-cultural, so it is relatively preferred compared to the term pluralism. Some (especially among anthropologists) use the term multiculturalism to describe a society that becomes the destination of migration and cultural exchanges which is different in the context of Indonesia. In Indonesia, most anthropologists prefer the term cultural diversity rather than multiculturalism. This kind of debate was once brought by Will Kymlica.

Specifically, the study in this paper is based on the description viewed from the Islamic perspective, i.e. the customs or information conveyed by the muslim scholars interpreting Islamic texts: the Quran, Hadith, statements of 
the companions, as well as a growing tradition in the Islamic world. Therefore, it is very likely that there might be a difference of understanding of the text used as the authentic basis in this paper when compared to the interpretation made by other parties. It is the evidence of the diversity of cultures because the definition of the author's background, history, and so on is also expected to give an explanation for the study conducted.

Nevertheless, differences in the interpretation of the diversity in this study will not be the focus. Theymerely show how the various perspectives of one text that is used by an author in making interpretation. With such explanation, it is expected to provide a concise description of the study here which focuses more on the definition of text rather than the differences over its meaning. The difference of meaning of the text can also be referred to as the wealth of the Islamic culture and Islam itself in terms of the interpretation of a term, including the controversial one commonly found in Indonesia.

\section{THE THEORY OF MULTICULTURALISM}

The year 2013 brought expectationsto many parties, particularly due to theoften rowdy and noisy"political festivity" that will be held in 2014. These expectationsare among others: guarantee of the religious freedom and rights of the minorities,no more discriminatory acts, religious-based conflict resolution can work properly, so as to prevent interreligious conflict. Such conditionsare expected not to happen again, especially against minorities who often become the targets of the majority's disappointment, even if it is just a group of people acting in the name of the majority of Muslims.

Multiculturalism is the term that best represents an overview of Indonesia. It is hard to find a better term that describes the real condition other than by mentioning Indonesia as a plural country. Therefore, Muslim writers such as Farid Esack, Abdul Aziz Sachedina and Syed Hashim Ali argued that multiculturalism has existed in Islam from the beginning and cannot be denied. Multiculturalism has become sunatullah, the will of God, so opposing it is similar to acting against God who has willed so. According to Farid Esack (1997) multiculturalism is the condition of a person who can accept and acknowledge differences and diversity. Multiculturalism goes beyond the tolerance and differences, as it is present a sincere person and in action against other parties who are different ".

Similarly Syed Ali Hashim stated that multiculturalism is "the condition of society in which cultural, religious groups, and ethnic groups lived side by side in a nation (country). Multiculturalism also means that reality is composed of 
many of fundamental substances. Multiculturalism is also a belief that there is no system identifier (understanding) or single view of reality that can explain the reality of life. See also statement of Abdul Aziz Sachedina (2001), in his book on pluralism. Sachedina said that pluralism is a term or word summary to mention a new world order where diverse cultures, belief systems and values evoke the excitement of various human expressions which never run out and inspire solutions to unresolved conflicts".

What religious people fear mostregardingproblems related to religion such as deviating religious teachings, and so on do not appear to be in the substantial explanation about multiculturalism, but sometimes appear in some views and informal discussions going on in academic forums in addition to investigations in the forums that multiculturalism is a vehicle towards one's faith toward the unification of religions so that religions seem to make no difference. Something like this should be responded carefully because improper response may lead to not only worthless discussion, but also a misunderstanding that keeps recurring and thriving in society at large.

The three Muslim scholars' explanation above can be concluded that multiculturalism is not contrary to Islam at all. Multiculturalism is the objective conditions in the field which requires Muslims and people of other religions mutually understand, respect, and take care of each other. These conditions can be created and among fellow believers who should unequivocally reject and prevent if there are groups of people who wish to destroy the objective conditions of multiculturalism. Such attitude will ensure that multiculturalism in Indonesia will last. Thus, there is no need to worry about multiculturalism, or in other words, there isnothing to worry about regarding faith and religion. The multicultural condition, according to the theoriesdeveloped by the Islamic scholars, does not necessarily make all religions similar. In fact, the concept of multiculturalism is to keep an objective condition that cannot be destroyed by anyone. Excessive concern about multiculturalism is unfounded.

\section{CHARACTERISTICS OF MULTICULTURALISM}

Based on the opinions expressed by the Muslim scholar above, it can be concluded that multiculturalism should become part of people's lives in a region of a stateon Earth. The opinion that multiculturalism destroyssomeone's belief cannot be justified and is absolutely unfounded. As a matter of fact, multiculturalism serves as the power to strengthen one's faith, not the other way round.

Such explanations must be emphasized because manypeople think that 
multiculturalism only makes society fragile and causes a person to be against religion and beliefs that became his conviction. In fact, multiculturalism is the doctrine of the faith of a person based on the uniqueness and characteristics of beliefs that one adheres to, and thus only one should respect, value, and appreciate the existence of diversity and heterogeneity to build a better community life. There should not be any group who wishes to destroy heterogeneity which becomes the will of God. This is the hallmark of multiculturalism which is often wrongly understood that multiculturalism seems to wish to equate all religions and urge people to change religion. This kind of opinion, based on the view of the three Muslim scholars above, is clearly unjustified. Therefore, it is clearlyincorrect to say that multiculturalism is the view of equating all religions and invite people to leave their faith.

A Muslim researcher of multiculturalism, Farid Esack even explained that the Qur'an from the beginning indeed appreciates the existence of multiculturalism, as in the use of the termsthe people of Prophet Noah, the people of Prophet Luth, the people of Prophet Abraham, and so on. Meanwhile, on other occasions the term human being a whole is used. This shows that in the case of certain cases, the Quran uses special terms like "O believers, the $k u f r$, the wise and so on, but for other common cases, theterm used is human. This is evident that the element of multiculturalismis found in the Quran.

In the meantime, Will Kymlica, an expert in politics and multiculturalism, provided a more political and sociological explanation on the nature of multiculturalism by comparing the systems of governance that flourished in the time of ancient Rome with the political system developed in Turkey, the French system of millet and Canada as a study of contemporary multiculturalism. Kymlica explained how differences in political system are implemented, but the four systems have its respective uniqueness, not the same in applying its policies on society. All four are based on their own characteristics, among others, mutual respect and respect for the diversity of cultures and political systems.

Each community that has a different culture and value system will easily embracedifferent values. Muslims for example will earnestly attempt to apply the command of the Holy Quran so to be righteous and faithful,and not to bekufr and dzalim. Christians will also do their best to comply with the teachings of the Bible and Jesus Christ, and so on.Each religion has its own example where diverse people cannot impose their will on others the people because they are different. There is no compulsion in religionaccording to the Quran, the Holly Book that serves as the main guideline for every Muslim.

In fact, even a society of a country has a very strong culture of diversity. In 
Indonesia, for example, there are strong cultural differences between the communities of Javanese and the Papuan in practicing everyday life. The Javanese people often believe the events that occur in the community serve as a sign of a larger event. For example, a disaster that befallsa family continuously is believed that a large disaster will occur in the surrounding communities even on an island. Meanwhile, in Papua, such a belief is not so strong.

Another example is related to the daily customs of in society. In the Javanese community, for example, if you walk with your friends past your home, youwill say "please stop by" as a sign of small talk with friends. The Javanese say "monggo mampir", (please stop by)because they are being polite. Whether you drop by or not does not really matters. In Papua, a habit like that is nowhere to be found. This case is also common in other areas.

Some of the examples above explain the objective conditions of multiculturalism which becomes Indonesia's wealth, either in terms of religion and culture which isfound in the midst of the community. The various traditions give an overview to the public that Indonesia's objective conditions may be different from one community to another. Therefore, we must appreciate and acknowledge the existence of differences of culture and religion which is very crucial and has become eternal necessity.

\section{THE ISLAMIC PERSPECTIVE}

Studiesconducted byMuslim scholars on multiculturalism can be presented in the following section. However, it should be noted here that the analysis in this section is only a fraction of the research both from overseas and within the country, as well as interviews with some of the scholars who are concerned with the theme of multiculturalism in Indonesia. Study on multiculturalism in Islam is often understood as pluralism, though there is a substantial difference. As already mentioned at the beginning, pluralism tends to be related to religious issueswhile multiculturalism is used with regard to social, cultural, and political issues. However, in practice, it is often used interchangeably, sowhen certain groups hear the term multiculturalism, they immediately likened to pluralism, whose existence has been politically rejected by several Indonesian Islamic groups.

The term multiculturalism is often used interchangeably with the term pluralism because this is actually related to the question of globalization where people of different religionsin the worldare faced with serious changes in the world globally, so religious followers could not turn a blind eye at each other. In fact, religiouspeoples should promotemutual learning and mutual respect of each 
other. Here lies the political issues, and the question of religious proselytizing becomes a serious issue among the adherents of the religions of Abraham.

In fact, if carefully analyzed, multiculturalism has been in existence since the days of ProphetMuhammad in Islam. In the Qur'an, it has been mentioned clearly about the condition of multiculturalism that should be appreciated and recognized by the followers of Muhammad (peace be upon him) and the people of the other prophets. There is no doubt about the meaning of the Holly Book over the recognition of multiculturalism. Nevertheless, the rejection of multiculturalism often occurs due to lack of knowledge and information. The most obvious example of how the Qur'an recognizes and respects multiculturalism is stated in verse 13 Surah al-Hujurat, which means: "O mankind, indeed We have created you from male and female and made you peoples and tribes that you may know one another. Indeed, the most noble of you in the sight of Allah is the most righteous of you. Indeed, Allah is Knowing and Acquainted."

The verse indicates that the diversity of the human race with all the background is indisputable. The diversity of cultures is the will of God Almighty. Then, why do people often attempt to negate diversity which has become God's will? It is because political issues that are plaguing their hearts and minds. The above verse clearly shows that only people who are committed will get the reward from God among all human beings, not because of differences.

Note also the following verse that suggests the existence of multiculturalism in cultural and socio-cultural situations. We should be concerned of humanitarian issues, not matters of differences betweendifferent followers of the prophets as explained in the Quran as follows: "O you who have believed, believe in Allah and His Messenger and the Book that He sent down upon His Messenger and the Scripture which He sent down before. And whoever disbelieves in Allah, His angels, His books, His messengers, and the Last Day has certainly gone far astray. "(An Nisa: 136).

The above verse firmly gives orders to human beings to believe in God, His Apostles, and HisHoly Books that have been revealed to His prophets before Prophet Muhammad. Meanwhile heathenism is shutting oneself to the truth that God has already revealed to all mankind, either now or before, namely the prophetic times before Muhammad. We are commanded to honor and acknowledge the existence of the earlier prophets, the prophets before Muhammad, and took lessons from the Books of the prophets before Muhammad, for it is a characteristic of people of faith. In the above verse it is also confirmed that reward is given to those who do well with passion rather than those who mock or hate others for practicing different religions and 
beliefs in life. In fact, we have to respect anyonewho differs in religious belief and God will see the real adherents of the religion. Doing good is the essence of all religions, in addition to the belief on what is practiced during life.

Note also the words of God that require Muslims to respect the places of worship of non-Muslims, Christians, Jews, and the Majusi. The Quran mentions explicitly: "And who are more unjust than those who prevent the name of Allah from being mentioned in His mosques and strive toward their destruction. It is not for them to enter them except in fear. For them in this world is disgrace, and they will have in the Hereafter a great punishment." (Al-Baqarah : 114).

The above verse asserts that "the mosque" is a place of worship used to worship God no matter where we are. "The mosque" is the name of a place of worship of Muslims, while temples, churches, monasteries, and synagogue are places of worship to say the names of God with a term known in various religions on earth. Therefore, God Almighty questions those disbelieve and destroy places of worship where God's name is echoed. This verse clearly says that every religious group must respect places of worship of different religions, and not to disgrace and ruin them. Being derogatory to or damaging places of worship of different people willbe severely punished by God. Anyone who insults and hates other faiths will receive God's wrath.

Syafiq Hasyim, a scholar of the NU (Muslim Organization) gave an explanation that multiculturalism has been going well since the days of the Prophet and the post prophetic with various kinds of events that can be taken as lessons for Muslims on Earth, including in Indonesia. He explained that the duty of a Muslim to seek knowledge into the land of China is a form of homage to the Chinese which was known for its Buddhism, not the Islamic religion. The tradition in China was different from that of the Middle East where Islam came from. The suggestion that Muslims learn until far into the country of China gives a sign that Islam is a religion that really appreciates the civilizations of other nations, not only the Islamic civilization itself. Civilization is a sign of a developed nation that has confidence about the future.

In the social sphere, as the faithful, wemust help each other despite different religions. In the theological sphere, different beliefs should respect each other for God has sent His Apostles and revealed His Books in every prophetic period. The race in the virtues is expected to bring good among believers. This verse thus can unequivocally be described as theological and sociological ground for the appreciation and acknowledge the existence of multiculturalism in Islam to other religions. Therefore, the tolerance shown by Prophet Muhammad to other believers is not an odd stance because the Quran teaches about tolerance 
toward people of other faiths. In fact, it is weird to oppose the tolerance that Prophet Muhammad taught during this time in the Treaty of Medina. What Prophet Muhammad did was God's instructionthat must be observed by every Muslim. Religions must uphold the attitude of compassion, mutual respect, and respect for religious beliefs and differences, no judging others based on hatred.

Serious question here can be asked here, why do most Muslims reject the lessons contained in the Qur'an and the Sunnah of Prophet Muhammad about multiculturalism and religious tolerance? There are several groups who continue to spread hatred toward people of another religion, even among people of the same faith by using physical and non-physical terror in the form of inappropriate statements. This is what needs to get serious attention forIndonesian Muslims as the majority in terms of adherents of the religion of Abraham.

\section{INDONESIA NATIONALISM}

Nationality is a concept that became a uniting power echoed by the founding fathers of this country. The founding fathers (known locally as the proklamator) Sukarno and Hatta,stressed that although we are different but we must remain united: one language, one nation and one state that is Indonesia. Therefore, Leo Agustino said when interviewed about nationality that "the national unity must be positioned in the conception of unity in diversity, rather than the unification (of differences)."

The people of Papua think that they are a nation of Papuabecause theybelong to a different race which is the Melanesian. The Melanesians are very different from most Indonesian. According to Agustinus, in the eyes of the people of Papua, the concept of nationality in this context ismerely a role model, subject to the Government as citizens but their awareness is of the Melanesian. Things like this are harmful if not immediately resolved, because gradually it will spread that Papua is not a part of Indonesia. Thus, building the capacity of Papua will become the cornerstone of building nationalism, especially by the higher educational institutions and the Government. One of the ways of making Papua to remain part of Indonesia is by eliminating a negative stigma about the Papuan communities and discrimination against them. Discrimination is a form of lack of recognition of nationhood, but Papua is part of the community of the Republic of Indonesia; they just happen to have different skin and hair.

Some cases of conflict in Papua since integrated intoIndonesiaare not fully resolved, and should be reviewedto find an alternative solution according to 
the applicable law. Marginalization is happening in Ambon, characterized by the economic issues, and will continue to cause a prolonged conflict if there is no settlement. The lack of state recognition of the rights of the indigenous people of Papua and Aceh will become barrier factors for them to become part of Indonesia. This dominant factor has resulted in the fact that Papua and Aceh feel they are not part of Indonesia politically, economically and culturally.

Nevertheless, the fact there is a strong belief that the people of Papua havestrong nationalism. The proof for this, for example, in certain indigenous culture (in Serui, Jayapura, Biak, Sorong) when there a wedding event especially in the proposing process, in addition to the dowry brought to the bride, they also carry a red and white (the Indonesian) flag not the OPM. This shows that Indonesia is still a symbol of nationalism in Papua. In fact, now there is a growing awareness in the community that the people of Papua should refuseto be subject to economic and political interestsfor the elites and foreigners, said Muridan S Widjoyo.

When outside of Papua, for example in Yogyakarta,the Papuan students always call themselvesthe Papuans rather than Indonesians. According to the Papuans, the construction of their mindset outside Papua is that they look at themselves as belonging to a different group from Indonesia. Therefore, according to Ave, to reconstruct their nationalism is to build the construction of Papua based on the local wisdom or wealth locally owned in the form of many traditions, such as dance, art, customs, and religion. From there, nationalism will emerge from the Papuans and other tribes in Indonesia. Nationalism will grow stronger when the Government gives attention to their community. In national and international events, Papuans are contributing in defending nationalism in national and international sporting events. This shows that the community actually has fostered a strong Indonesian awareness, not independence from Indonesia.

In order for the Papuans to really become part of Indonesia, the Government of Indonesia should improve their well being in the sense that they are not discriminated andmarginalized, and their natural resources not be exploited. If the Papuansenjoy justice, equality, and recognition, they will have stronger nationalism. However, if what mentioned is not met, a wave of protests and demonstration is inevitable. Consequently, they are referred to as Indonesians but emotionally they are a nation of Melanesia consisting of various tribes (Arfak in Manokwari, Asmat in Marin, Yakal in Maroke, Mee in Panai, Yali andand Lani in Wamena, the Komoro and Amungne in Timika).

In the context of the people of Aceh who embrace a culture of patriarchy, it is the responsibility of everyone in Aceh, especially men,to continue the 
Acehnese culture. Therefore, for the people of Aceh, the issue of ethnicity is very important because it also concerns the question of identity. In this context, when there is a question about nationality, theywill answer that we belong to the nation of Aceh, butthe state of Indonesia. Every descendant of the Acehneseis aware of and sensitive to the ethnicity that forms the identity of their culture. However, one cannot say that sincethe Acehnese are identical with the Islamic culture,they are not part ofIndonesia. This is because in the history of Aceh,it supportedthe Indonesia's independence and gavea lot of contribution to the continuity of the nation of Indonesia. Therefore, the people of Aceh form a community that has a historical bond of the Indonesian nationalism since the time of pre independence. The history of the nation of Aceh is indeed different from that of the Javanese, but by no means Java is better than Aceh.

Related to the above mentioned matters, Muhammad Taufik emphasized that multiculturalismis important for any nation to recognize so that its generation can be unified to developed capability and potential for competitiveness. Multiculturalism is not paranoid and taksub (selfishness, hatred, and enmity), but is meant to build the nation's consciousness toward a better direction without forgetting the history and roots of civilization. The political transformation of the Acehnese in the present context should be developed towards the consciousness of the elite, and the youth of Aceh, in particular, felt disoriented. The Acehnese youthin the future must be able to translate the Helsinki MoU so that sustainable peace will continuein Aceh, he said. To that end, he emphasized that the youth need to develop awareness and be able to formulate a more progressiveand substantive multiculturalism. The articulation of the role of youth in Aceh, he said, is still much awaited and needed. The implementation of the Helsinki MoU has yet to go as it should, both on the side of the Government of Indonesia and the Aceh authority.

Furthermore, Taufik affirmed that when multiculturalism is fading among the younger generation, it will lead to demoralization of the nation. We must not forget that the multiculturalism in contemporary political context of Aceh has just begun. Therefore, it is necessary to ensure that the bitter experiences of the past are not to be repeated. The Helsinki pactis a new movement between Aceh and Indonesia. The question is how to build nationalism in the form of ideas and practice. Looking ahead, how consciousness is truly built, so the political identity and integrity will be peaceful and comprehensive, safe and dignified for Aceh and Indonesia. Without pioneering, the youth can only dream to achieve it. Aceh is a society which has been joined by Indonesians.It has its own culture, i.e. the custom is based on the religious law and the religious 
law based on the Book of Allah.However it does mean Aceh must break away from and fight Indonesia.It should not beunderstood that way.

During Suharto's reign, according to most observers and experts, Aceh was in an unfortunate position which ledto separatism emerged. When Suharto came to power, Aceh was witnessing genocide and destruction. Aceh was the area of military operations where the risk of the military personnel raping women in Aceh was high. The people of Aceh felt the heartache. When Aceh demanded justice, the government answered with military actions. Activists and NGOs emerged in response to the Aceh conflict. The natural resources were exploited for the benefit of Indonesia and foreigners not forthe prosperity of Aceh. Therefore, GAM demanded independence,and the referendum was granted.

\section{THE FUTURE OF MULTICULTURALISM}

The future of Multiculturalism will thrive if we are sincerely willing to expand it in three domains at once. First, in the religious discourse (Islam and Christianity), as the two religions are most often considered problematic in Indonesia. A superficial understanding of religion is the cause of the rise of fundamentalism and radicalism which endanger the lives of the believers wherever they are. A superficial view on religions, including religion itself causes no positive perspectives about the presence of other religions and other groups in the internal religion. In fact, what is developed is hatred and suspicion when there are other groups who seek dialogue and cooperation with a different view and religious belief. Therefore, the shallow religious views of one's own and other people's religion that become a barrier against the perspective of multiculturalism twill hopefully evolve into a global and modern life today. One of the models that can be developed to reduce the exclusivism and radicalism is by opening dialogue and making visitsbetween adherents of religions for mutual learning the different religions will open the horizons of different religious followers.

Secondly, at the formal and legal level, strengthening of the law according to the scripture of each religion of Abraham (Judaism, Christianity, and Islam) to make the law contained therein obeyed by the community. The sacred religious texts already explain or demonstrate the way of life based on tolerance, mutual respect, and recognition of the existence of other people should always be strengthened. A construction must be built on mutual agreement between people who are different because without such agreement,social conflict between religious groups will be inevitable. The harmony between people of differentreligion is proof of the attitude of the true adherents. 
Third, in practicemulticulturalism exists in the texts but understanding it often doesnot run with the reality of the specified text. Fierce conflict in the name of religion is often made legitimized by some people as if it is based on the religious texts. The importance of understanding of religious texts thoroughly and openly should be prioritized by all parties so that understanding of the text into something open and able to develop mutual respect based on each social condition.

We should be aware that in a diverse society, people will make various interpretations of the religious texts. If those texts are negatively understood, it is not impossible the perspective of religions will be too narrow, and respect of other religious followers cannot be promoted. Inter-religious violence, though not approved by the majority of Muslims, will still continue to happen based on the legitimacy understood unilaterally.

\section{CLOSING REMARKS}

In light of the above discussion, multiculturalism should be examined in a more serious study so as to appreciate the cultural and theological diversity in Indonesia, both from the moral and theological aspect of jurisprudence, andshould bemore inclusive than the study of jurisprudence and theology. The interpretation of religious texts which is inclusive also contributes to the development of theological and multicultural perspective rather than developing theological narrow-mindedness. There is a lot of momentum which can serve as a point of departure for developing multicultural theology in Indonesia, at the moment the humanitarian issues emergingbefore so many believers, especially the Muslims.Floods, earthquakes, landslides, and ignorance that continue to haunt the entire country are things need a more serious consideration rather than busy taking care of other people's faith.

Judging by the very diverse condition, there is a final note regarding multiculturalism and nationalism in the context of Islam in Indonesia. We must realize that there are internal and external problems that affect religious understanding in this country. The internal factor is the highly diverse understanding --from moderate, progressive, to conservative--that influences each other in understanding of the Muslims in Indonesia. The internal Factor cannot be underestimated for it is perceived to be influential in the community, so it has to be an understanding that is able to push the development of multiculturalism and pluralism in Indonesia.

In addition to the internal factors, the external factors which come from outsidethe religious text whichinclude conditions of poverty, ignorance, 
and marginalization of the community are also very crucial issues. Unequal economic prosperity, education, and community development will easily become the driving force of the rift and social conflict. The textual basis of religion gives a framework that does not allow any killing or injuring others who differ from us. This is where external factors become important in terms of building conditions and the readiness of the community to adopt religious views, especially in Islamwhich include inclusiveness, tolerance, and pluralism.

If expectations for growth of and the multiculturalism and pluralism can be created simultaneously, in the future we will no longer find suspicion between religious groups just because we are different. Religious diversity should be understood assunnatullah (The way of God) which is of course the will of God that could not be rejected. In fact, denying the objective conditions of multiculturalismis contrary to the words of God Almighty, as clearly demonstrated in some religious texts.

\section{BIBLIOGRAPHY}

Ali, Hasyim. 2002. Islam and Pluralism, London: Sage Publication.

Elshtain, Jean E. 2008. “Tolerantion, Proselytizing and the politics of Recognition", Thomas Banchof, (ed.), Religious Pluralism: Globalization, and World Politics, Oxford: Oxford University Press.

Esack, Farid. 1997. Quran, Liberalism and Pluralism, London: Sage Publications.

Hasyim, Syafiq. 2007. Islam dan Multikulturalisme, Jakarta: ICIP.

Kymlica, Will. 2004. Kewargaan Multikultur, Jakarta: LP3ES.

Magnis Suseso, Franz. 1987. Kebudayaan Jawa, Yogyakarta: Kanisius.

Misrawi, Zuhairi. 2007. Al Quran Kitab Toleransi, Jakarta: Fitrah.

Murder, Niels. 2001. Kehidupan Sehari-Hari orang Indonesia, Malaysia dan Thailand, Jakarta: Gramedia.

Parekh, Bhikku. 2007. Rethinking Multiculturalism: Cultural Diversity and Political Theory, London: Sage Publications.

Sachedina, Abdul Aziz. 2001. Berbeda tapi Setara, Jakarta: Serambi.

Interview Report, Muhammad Taufik, 3/9/2012

Interview Report, Leo Agustino, 19 Maret 2012 